Dept. of Biomedical Science,

College of Vet. Med. and Animal Production,

Sudan University of Science and Technology, Sudan.

\title{
SOME NORMAL CONSTITUENTS IN SERUM AND CEREBROSPINAL FLUID IN SUDANESE CAMELS (CAMELUS DROMEDARIES)
}

(With One Table)

\author{
By \\ S.H. AHMED; SHADIA ABDEL ATTI OMER \\ and A.A. GAMEEL * \\ * Dept. of Pathology, Faculty of Vet. Med., University of Khartoum, Sudan. \\ (Received at 3/9/2009)
}

\section{SUMMARY}

Thirty clinically healthy male Sudanese dromedary camels were used in this study to determine some normal constituents of their serum and cerebrospinal fluid (CSF). On physical examination the CSF was clear and its viscosity was comparable to that of water. The CSF normal concentration were as follows total protein $(66.1 \mathrm{mg} / 100 \mathrm{ml})$, albumin $(26.3 \pm 0.02 \mathrm{mg} / 100 \mathrm{ml})$, urea $(17.93 \pm 0.27)$, uric acid $(2.17 \pm 0.04 \mathrm{mg} / \mathrm{ml})$, creatinine $(1.38 \pm 0.02 \mathrm{mg} / 100 \mathrm{ml})$, glucose $(167.59 \pm 2 \mathrm{mg} / 100 \mathrm{ml}), \mathrm{Na}$ $(121.67 \pm 0.49 \mathrm{mmol} / \mathrm{L}), \mathrm{K}(3.53 \pm 0.07 \mathrm{mmol} / \mathrm{L}), \mathrm{Ca}(5.65 \pm 0.02 \mathrm{mmolL})$, $\mathrm{Fe}(48.30 \pm 0.06 \mu \mathrm{g} / 100 \mathrm{ml}), \mathrm{Mg}(2.28 \pm 0.06) \mathrm{mg} / 100 \mathrm{ml})$, and the activities of the enzymes ALT(7.37 $\pm 0.18 \mathrm{U} / \mathrm{L})$, AST(21.13 $\pm 0.29 \mathrm{U} / \mathrm{L})$ and ALP $(76.0 \pm 0.38 \mathrm{U} / \mathrm{L})$ and their corresponding values in serum were $(7400 \pm$ $144 \mathrm{mg} / 100 \mathrm{ml}) ; \quad(3763 \pm 150 \mathrm{mg} / 100 \mathrm{ml}) ; \quad(28.7 \pm 1.42 \mathrm{mg} / 100 \mathrm{ml}) ; \quad(3.05 \pm$ $0.2 \mathrm{mg} / \mathrm{ml}) ; \quad(1.56 \pm 0.12 \mathrm{mg} / 100 \mathrm{ml}) ; \quad(162.16 \pm 18.8 \mathrm{mg} / 100 \mathrm{ml}) ; \quad(125.23 \pm$ $3 \mathrm{mmol} / \mathrm{L}) ; \quad(3.74 \pm 0.16 \mathrm{mmol} / \mathrm{L}) ; \quad(8.12 \pm 0.18 \mathrm{mg} / 100 \mathrm{ml}) ; \quad(59.67 \pm$ $4.08 \mu \mathrm{g} / 100 \mathrm{ml}), \quad(1.56 \pm 0.137 \mathrm{mg} / 100 \mathrm{ml}) ; \quad(11.67 \pm 1.75 \mathrm{U} / \mathrm{L}) ; \quad(34.73 \pm$ $1.87 \mathrm{U} / \mathrm{L})$ and $(84.50 \pm 1.50 \mathrm{U} / \mathrm{L})$ respectively. Serum had higher concentration of all the studied parameters than the CSF, except for the glucose level, which did not show any significant difference between the two fluids. The obtained values were discussed with other researchers reports in camels as well as with cerebrospinal fluid constituents in llamas and other domestic animals.

Key words: Sudanese camels, cerebrospinal fluid, biochemical profile. 


\section{INTRODUCTION}

Cerebrospinl fluid (CSF) is a clear ultrafilterate of plasma which is mainly produced by the choroid plexus and ependymal lining cells of the brain ventricles. It probably serves as a nutritive medium for the brain and spinal cord, provides mechanical support, regulates the chemical environment of the brain and acts as vehicle for transport of biologically active compounds (Kaneko et al., 1997). Cerebrospinl fluid compositional analysis have been widely used to monitor distortions in the brain metabolism, evaluate disruption of brain barrier transport and permeability functions, and identify biomarkers for diagnosis of CNS disorders (Kaneko et al., 1997; Johanson et al., 2008).

Thus, Cerebrospinl fluid provides a wide range of valuable biochemical and cellular information on neurological health of animals, and its composition is a subject to various environmental and physiological conditions and neurological disorders (Welles et al., 1992; Frosini, 2000 and Al sagair et al., 2005).

Cerebrospinl fluid composition is strongly dependent on that of blood and is a reflection of the blood plasma constituents. Normal values of CSF have been reported for many animal species including cattle, sheep, camels, horses, dogs, cats and some laboratory animals (Welles et al., 1992; Nazifi; Maleki, 1998; Stocker et al., 2002; Ameri and Mousavian, 2007; Achaaban et al., 2009 and Di Terlizzi; Platt, 2009)

In Sudan, there seems to be lack of information on normal CSF constituents in animals and standard values set elsewhere are usually consulted in neurological investigations. The objectives of this study was to establish normal range values for CSF for Sudanese dromedary camels in relation to serum which may be useful in clinical investigations of CNS diseases and in other pathophysiological studies.

\section{MATERIALS and METHODS}

\section{Animals:}

Serum and cerebrospinal fluid samples were taken from 30 apparently healthy male camels, about 10-12 years old, destined for slaughter at Tamboul abattoir. 


\section{Sampling:}

\section{1- Blood collection}

Blood was collected, immediately after slaughter from the jugular vein in plain vacutainers. Blood for determination of serum glucose concentration was collected in vials containing sodium fluoride. Serum was harvested by centrifugation of the blood at $2500 \mathrm{rpm}$. for 15 minutes.

\section{2- CSF collection:}

Cerebrospinl fluid samples were collected, into clean sterile containers, immediately after slaughter, through puncture of the cerebellomedullary cistern using sterile $10 \mathrm{cc}$ disposable syringes.

\section{Physical and Chemical Analysis:}

Color and consistency of CSF were tested visually. Serum and CSF concentration of total protein (TP), albumin(Alb), glucose, creatinine, urea, uric acid, $\mathrm{Mg}, \mathrm{Ca}, \mathrm{Fe}$ and the activity of the enzymes alanine aminotransferase (ALT), alkaline phosphatase (ALP), and asparate aminotranferase (AST) were determined by colorimetric method, using commercial kits (Linear Chemicals Ltd.- Spain) following the procedures set by the manufacturer. $\mathrm{Na}$ and $\mathrm{K}$ were measured by a flame photometer (Corning 400, England).

\section{Statistical analysis:}

The data were presented as means, standard error of the means (SEM) and range values. Comparison between the means was performed by student's t test as described by Gomez and Gomez, (1984).

\section{RESULTS}

On physical examination the CSF was clear white and did not clot. The results of the investigated parameters are shown in Table (1). 
Table 1: Mean \pm SEM and range of non-electrolytes, electrolytes and enzymes activity in Serum and CSF of Sudanese dromedary camels.

\begin{tabular}{|c|c|c|c|}
\hline Variables & $\mathrm{C} \mathrm{SF}$ & $\begin{array}{c}\text { Serum } \\
\text { Mean } \pm \text { Sd }\end{array}$ & Significance \\
\hline $\begin{array}{l}\text { Total proteins } \\
\mathrm{mg} / 100 \mathrm{ml}\end{array}$ & $\begin{array}{l}66.1 \pm 0.03 \\
63-6\end{array}$ & $\begin{array}{l}7400 \pm 140 \\
7400-8000\end{array}$ & $\mathrm{Hs}$ \\
\hline Albumin mg/100ml & $\begin{array}{l}26.3 \pm 0.02 \\
24-28\end{array}$ & $\begin{array}{l}3763 \pm 150 \\
3300-4000\end{array}$ & $\mathrm{Hs}$ \\
\hline Urea $\mathrm{mg} / 100 \mathrm{ml}$ & $\begin{array}{l}17.93 \pm 0.27 \\
16-21\end{array}$ & $\begin{array}{l}28.70 \pm 1.42 \\
26-31\end{array}$ & $\bar{S}$ \\
\hline Uric acid $\mathrm{mg} / 100 \mathrm{ml}$ & $\begin{array}{l}2.17 \pm 0.04 \\
1.8-2.6\end{array}$ & $\begin{array}{l}3.05 \pm 0.2 \\
2.6-3.5\end{array}$ & $\mathrm{~S}$ \\
\hline Creatinine $\mathrm{mg} / 100 \mathrm{ml}$ & $\begin{array}{l}1.38 \pm 0.02 \\
1.2-1.6\end{array}$ & $\begin{array}{l}1.56 \pm 0.12 \\
1.3-1.8\end{array}$ & $\mathrm{~S}$ \\
\hline Glucose $\mathrm{mg} / 100 \mathrm{ml}$ & $\begin{array}{l}167.59 \pm 2.00 \\
145-191\end{array}$ & $\begin{array}{l}162.16 \pm 18.8 \\
140-204\end{array}$ & NS \\
\hline $\mathrm{Fe} \mu \mathrm{g} / 100 \mathrm{ml}$ & $\begin{array}{l}48.30 \pm 0.06 \\
40-55\end{array}$ & $\begin{array}{l}59.67 \pm 4.08 \\
50-67\end{array}$ & $\mathrm{~S}$ \\
\hline $\mathrm{Ca} \mathrm{mg/100ml}$ & $\begin{array}{l}5.65 \pm 0.02 \\
5.5-5.9 \\
\end{array}$ & $\begin{array}{l}8.12 \pm 0.18 \\
7.8-8.5 \\
\end{array}$ & $\bar{S}$ \\
\hline $\mathrm{Mg} \mathrm{mg/100ml}$ & $\begin{array}{l}2.28 \pm 0.02 \\
2.1-2.6\end{array}$ & $\begin{array}{l}1.56 \pm 0.14 \\
1.3-1.8\end{array}$ & $S$ \\
\hline $\mathrm{K} \mathrm{mmol} / \mathrm{L}$ & $\begin{array}{l}3.53 \pm 0.07 \\
2.9-4.1 \\
\end{array}$ & $\begin{array}{l}3.74 \pm 0.16 \\
3.5-4\end{array}$ & $S$ \\
\hline $\mathrm{Na} \mathrm{mmol} / \mathrm{L}$ & $\begin{array}{l}121.67 \pm 0.49 \\
118-127\end{array}$ & $\begin{array}{l}125.23 \pm 3.0 \\
119-130\end{array}$ & $\bar{S}$ \\
\hline AST U/L & $\begin{array}{l}21.13 \pm 0.29 \\
19-24\end{array}$ & $\begin{array}{l}34.73 \pm 1.87 \\
31-38\end{array}$ & $S$ \\
\hline ALT U /L & $\begin{array}{l}7.37 \pm 0.18 \\
6-9\end{array}$ & $\begin{array}{l}11.67 \pm 1.75 \\
10-16\end{array}$ & $\mathrm{~S}$ \\
\hline ALP U /L & $\begin{array}{l}76.00 \pm 0.36 \\
70-79\end{array}$ & $\begin{array}{l}84.50 \pm 1.50 \\
82-87\end{array}$ & $S$ \\
\hline
\end{tabular}

Hs $(\mathrm{P}<0.001)$

$\mathrm{S}(\mathrm{P}<0.05)$

\section{DISCUSSION}

Cerebrospinl fluid proteins were determined, as an index of the integrity of the blood-brain barrier. The mean value of TP obtained $(66.1 \pm .03 \mathrm{mg} / 100 \mathrm{ml})$ for Sudanese dromedary camels (Table 1) accords 
with the maximum value found in adult llamas (Welles et al., 1994), and the mean value $(0.66 \mathrm{~g} / \mathrm{l})$ reported early for rabbits (Weisbroth et al., 1974). Lower values than of the present work are reported in dromedary camels by Al-Sagair et al. (2005) and Nazifi and Maleki (1998) for fasted camels in Iran (32 mg/dl), St Jean et al. (1997) for 8 weeks old calves, Ameri and Mousavian (2007) for sheep, and Jass et al. (2008) for rabbits. A variation in CSF concentration of TP was found between young and old camels (Al-Sagair et al., 2005), mature and immature equines (Rossdale et al., 1982). The serum albumin concentration was higher than that of the CSF. Cerebro-spinal fluid albumin concentration was within the range reported by Welles et al. (1994) for llamas (11.8$27.1 \mathrm{mg} / \mathrm{dl})$.

The creatinine, urea, and uric acid concentration in CSF were significantly lower $(\mathrm{P}<0.05)$ than that of serum. In man these substances are not associated with specific diseases; so their usefulness in clinical diagnosis is not evident (Fishman, 1992); yet their role in veterinary medicine has to be investigated. Al-Sagair et al. (2005) found higher CSF concentrations of uric acid and urea but lower creatinine values in older camels than in young ones. The mean urea value of the present work is in line with the value $(3.15 \mathrm{mmol} / \mathrm{L})$ reported in camels by AlSagair et al. (2005), but is higher than the values reported in the Iranian Dromedary camels $(5.5 \mathrm{mmol} / \mathrm{l})$ by Nazifi and Maleki, (1998). Lower values than ours $(2.08 \mathrm{mmol} / \mathrm{l})$ are found in sheep and goats (Aminalari and Mehran, 1988).

Kaneko et al. (1997) claimed that the normal concentration of creatinine in Cerebrospinl fluid is approximately two thirds that of plasma. CSF creatinine level in the present work was $88 \%$ of the serum creatinine level, which is higher than the $74 \%$ shown in Iranian camels (Nazifi and Maleki, 1998). However, lower CSF creatinine values are reported in camels (Al-Sagair et al., 2005) and in Holstein calves (St Jean et al., 1997).

In the current study glucose was the only analyte that did not vary significantly between the serum and CSF. The range of CSF glucose concentration in Sudanese camels is comparable to that reported in llamas $(86-159 \mathrm{mg} / \mathrm{dl})$ by Welles et al. (1994), while the mean value is higher than those reported in camels (Nazifi; Maleki, 1998 and Al-Sagair et al., 2005); sheep (Ameri and Mousavian, 2007) and in 8 weeks old Holstein calves (St Jean et al., 1997). Kaneko et al. (1997) reported that, the concentration of CSF glucose depends upon the blood glucose concentration, the rate of glucose transport into the CSF and the 
metabolic rate of the central nervous system; this may explain the variation in the CSF glucose concentration between the current work and the other studies.

Serum electrolytes levels are significantly higher than CSF electrolytes concentration. The level of some CSF electrolytes concentration is determined in view of their importance for diagnosis of salt poisoning and for assessment of fluid therapy (Welles et al., 1992). Sodium and calcium are particularly important in the establishment of the thermal set point in the hypothalamus (Myers and Veale, 1970). K concentration in the current study is comparable to the mean values found in camels (Nazifi and Maleki, 1998; Al-Sagair et al., 2005) and the range obtained by Welles et al. (1994) for llamas. Higher $\mathrm{Na}$ concentrations were reported in camels (Nazifi and Maleki 1998; Al-Sagair et al., 2005), llamas (Welles et al., 1994) and in sheep (Ameri and Mousavian, 2007). Calcium concentration in the current study accords well with that reported in horses by Kaneko et al. (1997). The activities of the enzymes (ALT, AST, ALP) in the CSF are significantly lower than that of the serum and are much higher than those reported by Achaaban et al. (2009) and Nazifi and Maleki, (1998) in camels.

The variations observed in the values obtained in this study when compared with those of other researchers can be attributed to animal species, age, breed (Stocker et al., 2000), stage of maturity of the brain blood barrier, site of sampling, time of analysis after sampling, storage conditions (Fry et al., 2006; Andrews et al., 1994), and or techniques used for biochemical analysis.

\section{ACKNOWLEDGMENT}

This work was kindly supported by The Scientific Research Council -Sudan University of Science and Technology.

\section{REFERENCES}

Achaaban, M.R.; Baiss, M.; ElAllali, K.; Oukesson, M. and Pirou, M. (2009): The cerebrospinal fluid in the dromedary camel (Camelus dromedaries): sampling and composition. Second Conference of Isocard: Djerba (Tunisia).

Al-Sagair, O.A.; Fathalla, S.I. and Abdel-Rahman, H.A. (2005): Reference values and age related changes in cerebrospinal fluid and blood components in the clinically normal male Dromedary camel. J. of Animal and Vet. Advances 4: 467-469. 
Ameri, M. and Mousavian, R. (2007): Analysis of cerebrospinal fluid from clinically healthy Iranian fat-tailed sheep. Veterinary Research Communication, 31: 77-81.

Aminlari, M. and Mehran, M.M. (1988): Biochemical properties of cerebrospinal fluid of sheep and goats comparison with blood. Journal of Veterinary Medicine 35: 315-319.

Andrews, F.M.; Geiser, D.R. and Somardah, C.S. (1994): Albumin quotient, IgG concentration and $\mathrm{IgG}$ index determination in cerebrospinal fluid of neonatal foals. Am. J. Vet. Res. 55: 741-745.

Di Terlizzi, R. and Platt, S.R. (2009): The function, composition and analysis of cerebrospinal fluid in companion animals: Part IIAnalysis. Vet. J. 180: 15-32.

Fishman, R.A. (1992): Cerebrospinal Fluid in Diseases of the Nervous System. $2^{\text {nd }}$ ed. Saunders: Philadelphia -Pennsylvania.

Frosini, M.; Sesti, C.; Mitri, P.; Valoti, M.; Fusi, P.; Bianchi, L.; Laura, D.; and Sgaragli, G. (2000): Heat-stress- induced hyperthermia alters CSFosmolality and composition in conscious rabbits Am. J. Physiol. Regul. Integ Comp. Physiol 279: 2095-2103.

Fry, M.M.; Vernau, W.; Kass, P.H. and Vernau, K.M. (2006): Effects of time, initial composition, and stabilizing agents on the results of canine cerebrospinal fluid analysis Vet. Clin. Pathol. 35: 72-77.

Gomez, K.A. and Gomez, A.A. (1984): Statistical Procedure for Agricultural Research, $2^{\text {nd }}$ ed. Willy and Sons, Inc.

Jass, A.; Matiasek, K.; Henke, J.; Kuchenhoff, H.; Hartmann, K. and Fischer, A. (2008): Analysis of cerebrospinal fluid in healthy rabbits and rabbits with clinically suspected encephalitozoonosis The Veterinary Record 162: 618-622.

Johanson, C.E.; Duncan, J.A.; Klinge, P.M; Brinker, T.; Stopa, E.G. and Silverberg, G.D. (2008): Multiplicity of cerebrospinal fluid functions: New challenges in health and disease. Cerebrospinal Fluid Res.5: 1-57.

Kaneko, J.J.; Harvey, J.W. and Bruss, M.L. (1997): Clinical Biochemistry of Domestic Animals $5^{\text {th }}$ ed. Pub. Academic Press USA. p: 904.

Myers, R.D. and Veale, WL. (1970): Body temperature: possible ionic mechanism in the hypothalamus controlling the set-point. Science 170: 95-97. 
Nazifi, S. and Maleki, K. (1998): Biochemical analysis of serum and cerebrospinal fluid in clinically normal adult camels (Camelus dromedarius) Research in Veterinary Science 65: 83-84.

Rossadale, P.D.; Cash, R.S.G. and Leadon, D.P. (1982): Biochemical constituents of cerebrospinal fluid in premature and full term foals Equine Vet. J. 14: 134-138.

St Jean, G.; Yvorchuk, S.K.; Anderson, D.E. and Moore, W.E. (1997): Cerebrospinal fluid constituents collected at the atlantooccipital site of xylazine hydrochloride sedated, healthy 8week old Holstein calvesCan. J. Vet. Res. 61: 108-112.

Stocker, H.; Sicher, D.; Rusch, P. and Lutz, H. (2002): Reference values in the cerebrospinal fluid of calves between four and eight weeks of age Schweiz Arch Tierheilkd 1,44: 283-288.

Weisbroth, S.H.; Flatt, R.E. and Kraus, A.L. (1974): The biology of the laboratory rabbit.New York, Academic Press.pp62-65.

Welles, E.G.; Pugh, D.G.; Wenzel, J.G.W. and Sorjonen, D.C. (1994): Cerebrospinal fluid composition in healthy adult llamas Am. J. Vet. Res. 55: 1075-1081.

Welles, E.G.; Tyler, J.W.; Sorjonen, D.C. and Whatley, E.M. (1992): Composition and analysis of cerebrospinal fluid in clinically normal adult cattle Am. J. Vet. Res. Vol. 53: 2050-2057. 